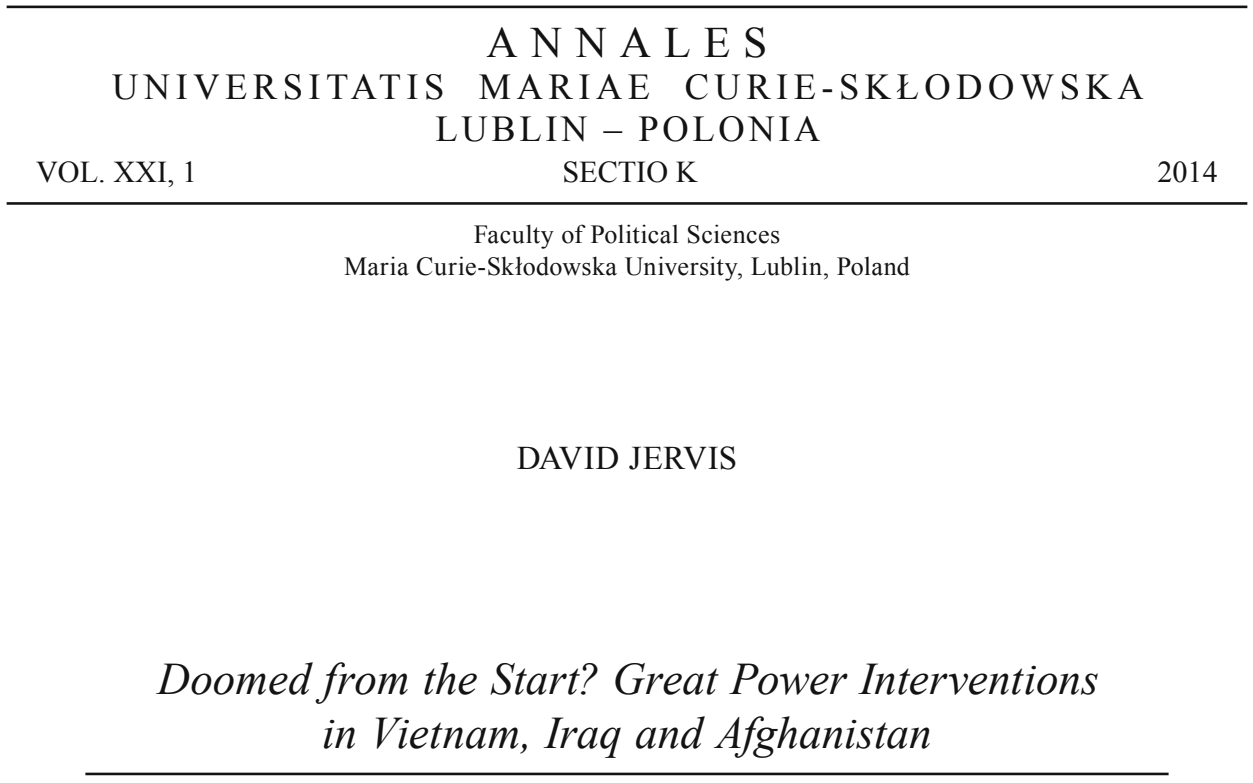

\title{
Doomed from the Start? Great Power Interventions in Vietnam, Iraq and Afghanistan
}

\begin{abstract}
This study identifies the attitudes and initial policies common to the British, French, American, and Soviet interveners in Vietnam, Iraq, and Afghanistan and links those attitudes and polices to the ultimate defeat of each of these interveners.
\end{abstract}

Key words: great power interventions, Vietnam, Afghanistan, Iraq

There is much debate about the similarities and differences between America's wars in Afghanistan, Iraq and Vietnam. One thing all three have in common is that the American intervention followed, often quite quickly, the failed intervention by another great power. Thus, America picked up in Vietnam almost as soon as the French had departed and came to Afghanistan little more than a decade after the Soviets had left. The Iraq case is somewhat different. America's intervention in 2003 quickly followed the 1990-1991 war against Iraq, but it did not invade and occupy Iraq, itself, at that time. However, the British had invaded Iraq during World War I and remained in the country as a League of Nations mandatory power until 1932. This history creates six cases of great power intervention: France in Vietnam from the end of World War II until 1954, America in Vietnam from the mid-1950s until 1973, Britain in Iraq from 1914-1932, America in Iraq from 2003-2011, the Soviet Union in Afghanistan from 1979-1989, and America in Afghanistan from 2001 to the present. 
Comparisons between these cases have tended to take two forms. One is to compare the American experience in one case with its experience in a later one. Thus, Robert Brigham and Jeffrey Record and Andrew Terrill compare Vietnam and Iraq, while Thomas Johnson and Chris Mason compare the American experiences in Vietnam and Afghanistan. The other common comparison is to focus on the experiences of different interveners in the same country, e.g., comparisons of the American and Soviet experiences in Afghanistan written by Jonathon Steele or of the French and early American experiences in Vietnam written by Frederik Logevall. There are few, if any, works that try to compare and contrast all six cases. This article is part of a much larger project that attempts to do so. It will document the failure of each of these interveners, identify their initial attitudes and policies, and conclude with a discussion of the impact of those initial attitudes and policies on their eventual defeat.

\section{OBJECTIVES AND OUTCOMES}

In none of these cases did the intervener realize its objectives. While the interventions were justified by both concern for the people in the target country and the interests of the intervener, the objectives of the intervener took precedence. A 1937 British retrospective on its mandate in Iraq made the point explicitly: 'Nations do not vie among themselves for control over lands...primarily to give justice or to raise the standards of living among the people...., it is 'very natural that the [interests] of the mother country should come first and that the goal of the people must, in reality, be subordinated to the expected material and political returns' [quoted in Sluglett 2007: 7]. Ninety years later, American interveners in Iraq were more blunt: Larry DiRita, Secretary of Defense Donald Rumsfeld's spokesman, stated just before the March 2003 invasion, 'We don't owe the people of Iraq anything. We're giving them their freedom. That's enough.' When it came to actual policy in Iraq, Rumsfeld had primary responsibility after the invasion, even though 'No one at the top of the [Bush] administration was less interested in the future of Iraq than Donald Rumsfeld' according to George Packer [both quoted in Jervis 2009: 131]. Similarly with respect to Vietnam, John McNaughton, an Assistant Secretary of Defense, argued in a 1965 memo that U.S. aims there could be divided as follows: $70 \%$ to avoid a humiliating American defeat, 20\% to keep the territory of South Vietnam from China, and 10\% 'to permit the people of SVN to enjoy a better, freer way of life' [quoted in Brigham 2008: 19]. The French sought to restore their colony in Vietnam when they arrived in 1945, something that would undoubtedly bring more benefits to the French than to the Vietnamese. One expects that the Soviets had little interest in the Afghan people when they arrived in 1979. Given these priorities, any evaluation of the outcome of these interventions must concentrate on the extent to which they furthered the narrow interests of the intervener.

What, then, were the primary goals of the interveners? Their goals were often similar. Protecting the geographic space of the target country from another power 
was one common motive. An important interest for the British in Iraq was to protect transit routes to India, the most important of its colonies. The Americans wanted to prevent South Vietnamese territory from being used by Communist China for further advancers in Asia, while the Soviets wanted to insure that the United States did not establish a foothold in Afghanistan to replace the one it had lost in Iraq.

Several of these interveners acted to protect or preserve a client, often doing so reluctantly. Most clear in this regard is the Soviet Union's invasion of Afghanistan. When the Soviets intervened in December 1979, they did so to save an Afghan client who had offended large swathes of the local population and was combating armed opposition. They intervened reluctantly; the Afghan government had appealed for Soviet military support thirteen times in 1978-1979 before the Soviets decided to invade [Steele 2011: 74]. Similarly in Vietnam, the United States only sent troops to Vietnam after a lengthy advisory effort had failed to thwart the challenge posed by opponents of the Saigon government.

The protection of the intervener's image was another common motive. France's intervention in Vietnam after 1945 sought to restore its image after its defeat in the early days of World War II; France could 'only be a great power so long as our flag continues to fly in all the overseas territory,' and Indochina was especially important as France's richest and most prestigious colony [Herring 2002: 6]. The Soviets feared damage to their image if they did not intervene in Afghanistan; the 'Russians could no more abandon Afghanistan than the Americans had felt able to abandon Vietnam in the 1950s and 1960s' [Braithwaite 2011: 47]. Later, as the intervener faced growing difficulties, the image interest took on a different character. There was the fear that, having made an investment in the country, its international prestige would suffer if it failed to persevere and win. In Richard Nixon's classic phrase, the United States would appear to be a 'pitiful, helpless giant,' if it did not act vigorously in Southeast Asia and if it failed to meet that challenge, 'all other nations will be on notice that despite its overwhelming power the United States, when a crisis comes, will be found wanting' [Nixon quoted in Cohen 1983: 283]. Soviet leaders contemplating withdrawal from Afghanistan had similar concerns: '... a withdrawal before Moscow's goals were achieved...might be seen as a defeat of the Soviet military. Such a defeat would be a blow to Moscow's prestige in the Third World and to its sense of parity with the United States...' [Braithwaite 2011: 52].

A final motive common to these interventions was the felt need to defend the target country and, ultimately, the intervener, itself, against some sort of nebulous foe. Thus, the Americans intervened in Vietnam to defend against international communism, the Soviets in Afghanistan to defend against Islamic fundamentalism, the Americans in Iraq and Afghanistan to defend against international terrorism, and the French in Southeast Asia to defend against the power of nationalism.

It is fair to say that none of these interveners attained their goals. Consider the goal of defending an embattled client. The United States left Vietnam with its client still in power, but that government could not stand on its own and was defeated within thirty months after the American withdrawal. Similarly in Afghanistan, the 
Soviet-backed regime remained in power for several years after the Soviets left, but it collapsed in 1992 when Russian aid (the Soviet Union had collapsed in 1991) was halted. Consider the effort to strengthen national prestige. French and American prestige was harmed by their continued stay and eventual defeats in Vietnam, perhaps more than would have been the case had they not intervened in the first place. The Soviets lost more than prestige during their stay in Afghanistan; the Soviet Union, itself, collapsed less than three years after the departure from Afghanistan and while there were many causes of that demise, the expenditures and losses in Afghanistan have to be counted among them. Consider the goal of defeating a nebulous ideology. Asian nationalism likely increased its potency after the defeat of the French in Vietnam, much like Islamic fundamentalism was boosted by the Soviet defeat in Afghanistan. As for terrorism, global terrorism has increased since the American interventions in Afghanistan and Iraq: the number of terrorist incidents worldwide increased 460\% between 2002-2011 [Institute of Economics and Peace 2012]. Finally, if the interveners sought to prevent the use of the territory by their foes, their defeat increased the likelihood that it would be.

\section{ARRIVING IN AND IGNORING A DIFFICULT ENVIRONMENT}

Realities in Vietnam, Iraq, and Afghanistan at the time of these interventions help explain their failure. For instance, both the Vietnamese and Afghans had long histories of successful struggles against foreign interventions. The Vietnamese had struggled for centuries against the Chinese, while the Afghans had fought and defeated invaders as far back as Alexander the Great in the fourth century BCE and as recently as the British in the nineteenth century [Karnow 1984: 101-38; Jones 2012: 1-8]. American interveners faced the additional difficulty that the Vietnamese had recently defeated the French and the Afghans had defeated the Soviets shortly before the Americans intervened. This provided them with both experience and confidence in their struggles against the Americans.

Further complicating the interveners' efforts was the political-military situation in the target country. The French sought to re-establish their colonial rule in Indochina five years after the Japanese had effectively ended it, a most unlikely project, especially since the Vietnamese had declared their independence at the very end of World War II and begun to organize a government. To regain political control over the country the French had to first regain physical control. The British and the Nationalist Chinese had responsibility for disarming the Japanese in the country and, while the British were happy to turn over control to the French as soon as possible, the presence of Chinese in the north allowed Ho Chi Minh's forces to build their strength there [Logevall 2012: 91].

While the Americans did not initially confront a military challenge in (South) Vietnam and Iraq, the prevailing political situation was quite complex. In South Vi- 
etnam, there was a need to create both a new state and a new nation the ashes of the French colony. That is, the administrative machinery of the new country had to be created and the South Vietnamese people had to develop loyalty to their new leader Ngo Dinh Diem, a difficult task under any circumstances, but complicated in this case by the fact that Diem was not the type of person best able to initiate such a program. He had been out of the country for four years and had not had administrative responsibility for twenty years. He was not a dynamic leader or one inclined to reach out to the South Vietnamese people to gain their support. He also faced a number of enemies in South Vietnam [Logevall 2012: 626-27]. Iraqi society was very fragmented and those knowledgeable about the country 'knew instinctively that the invasion of Iraq would open up the great fissures of Iraqi society, with enormous regional and international consequences' [Jervis 2009]. Moreover, long years of life under Saddam Hussein made politics an all-or-nothing struggle, leading the country's politicians to advance their factional interests rather than compromise.

Similarly, Soviet and American interveners in Afghanistan faced a very difficult political/military situation at the time of their arrival. The Soviets had supported the Afghan revolutionary government with aid and advisors since it had come to power in an April 1978 coup. That government's policies had stoked widespread opposition, and there was a virtual civil war at the time of the Soviets' arrival. The Americans in Afghanistan sought not to support an existing regime but to replace the Taliban government with one of their own making and to do so in an environment that was 'one of the most challenging environments for nation-building,' given the Soviet invasion, civil war, and rule by the Taliban in the two decades before the American arrival [Tierney 2010: 231-32].

The interveners were obviously not deterred by such challenging situations. While ignorance may explain why the intervener intervened despite these conditions, a better explanation is willful blindness to these realities. For instance, Americans went to Vietnam and Afghanistan soon after their extensive involvement in those countries' prior wars, supporting the French and opposing the Soviets. As Jonathon Steele has written with respect to Afghanistan, 'How is it that the Americans did not think more carefully before they plunged into Afghanistan. Had they really forgotten what had happened little more than a decade earlier when the Russians learned they could never beat a local insurgency?' [Steele 2011: 23-24]. The French were very familiar with Southeast Asia, returning to a region they had controlled as a colony for more than eighty years. The Soviets also should have known better. A leading Soviet scholar, Yuriy Gankowskiy, lamented at the time of the 1979 invasion that, "They don't know what they're doing. They're provoking a conflict, which could go on for centuries" [quoted in Tomsen 2011: 130]. Of the Americans in Iraq, 'it seems clear the Bush administration purposefully ignored the available intelligence on Iraq...' [Brigham 2008: 72]. In fact, members of the Bush administration even ignored the advice they had followed at the end of the first Gulf War in 1991. For instance, Dick Cheney, Secretary of Defense at the time of the earlier war, was adamant that the United 
States had been correct in not entering Iraq at that time, asserting in 1994 that 'Once you got to Iraq and took it over, what are you going to put in its place? That's a very volatile part of the world, and if you take down the central government of Iraq, you could very easily end up seeing parts of Iraq fly off....' And, after noting that only 146 Americans died in the first Gulf War, Cheney asked a rhetorical question that many might ask after the 2003 invasion, 'how many additional dead Americans is Saddam worth?' [quoted in Anderson 2011: 38-39]. But in 2003, Cheney, now Vice President, was one of the major cheerleaders for invading Iraq.

\section{GREAT EXPECTATIONS AND GREAT OPTIMISM}

Despite or, perhaps, because they ignored local realities, the interveners manifested great optimism at the outset. This is reflected in two senses, the magnitude of the goals they sought and the rapidity with which they expected those goals to be achieved. With respect to goals, the intervener sought nothing less than the creation of a stronger and more modern state in the target country. Richard Holbrooke, who worked in the American embassy in Saigon in the 1960s and later served as President Obama's special representation for Afghanistan and Pakistan, used a phrase, 'revolutionary colonialism,' that might well describe the interveners' goals in all of these cases. In Holbrooke's words, the U.S. commitment to South Vietnam would lure it "unwillingly and unwittingly into a strange sort of "revolutionary colonialism" - our ends are "revolutionary," our means are quasi-colonial' [quoted in Braithwaite 2011: 61].

Thus, in Afghanistan both the Soviets and the Americans sought to create a stronger state and one that would reform Afghan society. The Soviet leadership "envisioned Afghanistan as a "second Mongolia" which would leap from feudalism to socialism' quickly, according to one involved in decision-making [quoted in Tomsen 2011: 202]. The Americans hoped to bring domestic reform and good government to Afghanistan as well as to Vietnam and Iraq. The French in Vietnam had a very difficult challenge, trying to reestablish colonial rule in the aftermath of their defeats by the Japanese in Indochina and by the Germans in France, itself, in the early months of World War II. The British in Iraq and Americans in South Vietnam had even more challenging objectives, because in those cases, there had been no state in the period immediately preceding the arrival of the intervener. These states would have to be created from scratch.

Complicating the need to create a new state or a stronger state was the need in several of these cases to also create a new nation. Clearly, given the absence of an Iraqi or South Vietnamese state prior to the arrival of the British or Americans, there had been no Iraqi or South Vietnamese nation. Vietnamese nationalism, as distinct from South Vietnamese nationalism, actually worked against American efforts, because the majority of Vietnamese were loyal to the nationalist leader Ho Chi Minh. One can also ask whether there has ever been an Afghan nation except, perhaps, in 
times when the country's people unify against foreign invaders, or in Iraq, where it 'was no wonder that the Bush administration [had] such a difficult time....Ethnic, tribal, religious, social and political division are the hallmark of modern Iraqi history' [Brigham 2008: 77].

Not only did the interveners expect to accomplish grand objectives, but they expected to do so quickly. Perhaps the best example of optimism is America's plan for post-war Iraq. Initial plans were to hand control over to the Iraqis soon after the arrival of U.S. troops, most of whom would leave within six months. Yet the Americans were not alone in such optimism. Soviet Foreign Minister Gromyko predicted at the time of the Soviet invasion of Afghanistan that 'we'll do everything we need to in a month and then get out.' Party leader Leonid Brezhnev was not quite so optimistic, believing it might take several months to accomplish Soviet goals [quoted in Braithwaite 2011: 24]. For their part, the Americans sent few soldiers to Afghanistan when they invaded in October 2001, relying instead on air power and recruiting and supplying anti-Taliban Afghan warlords. The French, too, were confident of victory in Indochina. They thought the war would be a 'cakewalk' when they arrived in 1945. Although the next several years were difficult ones, French hopes revived in 1951 with the arrival of General Jean Latarre de Tassigny in Indochina. He promised victory in 'months, perhaps one or two years' [quoted in Morgan 2010: 101, 144]. Americans also used the word 'cakewalk' to describe the likely success of their efforts in Iraq, with one of Rumsfeld's assistants arguing that defeating 'Hussein's military power and liberating Iraq [will] be a cakewalk' [quoted in Anderson 2011: 127-29].

A way to demonstrate America's great optimism is to remember that it intervened in several of these countries in the immediate aftermath of a failed effort by another great power. The Americans knew much about the Afghans and their hostility to foreign powers, having exploited that during the Soviet occupation. Nonetheless, 'hubris led Washington to think it would be able to do a better job providing stability and progress than the Soviets had done' [Steele 2011: 394]. A similar label might describe America's actions in South Vietnam, coming as they did soon after American-assisted France had been unable to prevail there. While their invasions quickly followed the French and Soviet defeats, the Americans rejected any comparison. Secretary of State John Foster Dulles argued that the French experience was not relevant to the American efforts because 'We have a clean house there now, without a taint of colonialism'; the French defeat had been 'a blessing in disguise' [quoted in Logevall 2012: xxi]. Similarly, American officials bristle at any comparison of current American actions and the Soviet intervention in Afghanistan; Under Secretary of Defense for Policy, Michelle Flournoy, argued in 2009, for example, that, '[t]here's absolutely no valid comparison between the Soviet occupation of Afghanistan' and the current U.S. campaign to help the Afghan people 'reclaim their country' [quoted in Evans 2013]. In Iraq, the Americans had chosen not to invade in 1991, but in 2003 the Bush administration ordered the development of an invasion plan on November 21, 2001, just 72 days after 9/11 and before fighting in Afghanistan had ended or Osama bin 
Laden had been captured' [Anderson 2011: 95-96]. Moreover, Americans in later wars should have been cognizant of the problems the U.S. had had in Vietnam, but leading officials in the Bush administration rejected any comparisons: its grand strategy 'set out a policy line that denied that Vietnam had happened at all' [Brigham 2008: 175]. Rumsfeld rejected any comparisons between Vietnam and Iraq: 'Of course it won't be Vietnam. We are going to go in, overthrow Saddam, get out. That's it' [quoted in Anderson 2011: 103].

\section{GOVERNING THE OCCUPIED TERRITORY}

Having decided to enter the country, these interveners then had to decide how to govern it. One of two methods was used at the outset, direct rule using representatives from the capital of the intervener or indirect rule placing local faces on the immediate post-intervention government. Eventually, however, all of these interveners decided upon indirect rule. There are two cases where direct rule was first tried, the British in Iraq and the French in Indochina. In three later cases, the interveners wanted to place a local face on the intervention from the start, the Americans in Vietnam and both the Soviets and the Americans in Afghanistan. The American intervention in Iraq provides a bit of a different model; the U.S. had hoped to turn over control to Iraqis, especially returning Iraqi exiles as soon as the military phase of the invasion ended, but the invasion created so many local problems and the Iraqi exiles were so unpopular that the Americans soon decided - within six weeks of the invasion - to impose direct rule via the Coalition Provisional Authority. However, they, too, soon changed their approach, shifting to indirect within fourteen months. That is, local resistance led the Americans to decide upon direct rather than indirect rule in Iraq, while the pattern for the British in Iraq and French in Vietnam was the reverse, i.e., local resistance to direct rule led them to resort to indirect rule as a means of gaining some legitimacy and support for their efforts.

The British experience in Iraq illustrates the pattern. They had conquered the territory in World War I and received a mandate to govern it from the League of Nations. They first tried to impose direct rule. That prospect became impossible after the Iraqi revolt of the summer and fall of 1920, a revolt prompted by wartime promises of independence and by British indecision about the country's future. While eventually put down, the revolt cost the lives of about 6,000 Iraqis and 500 British and Indian soldiers. In the aftermath, the British determined that the costs of direct rule were too high and decided in favor of indirect rule. That approach would require the consent of at least some Iraqis as well as the installation of a local face for British rule. Not surprisingly, the British decided that the local face should be a king, naming Faisal, a leader in the Arab revolt in World War I. He was an outsider, being from contemporary Saudi Arabia. As an Arab, he did not have a lot of support among Iraqi Kurds and as a Sunni, he did not have a lot of support among the 
majority Shiites, a situation making him more dependent on the British. Faisal had some governing experience, having ruled briefly in Syria before being exiled by the French, an experience that demonstrated to him that the governing power would put its interests above his [Tripp 2007: 39-48; Sluglett 2007, 37-39].

The pattern of French rule in Indochina is similar. They initially imposed direct rule but then decided in the face of difficulties to try to give some legitimacy to their regime by recruiting a former emperor, Bao Dai, to return to power in 1949. Bao Dai had 'spent most of his life as a puppet of France and then Japan, whiling away the years by indulging an apparently insatiable taste for sports cars, women, and gambling' [Herring 2002: 23]. He had resisted French appeals to return to power after World War II, only relenting in March 1949 after they granted Vietnamese 'independence,' while retaining control of the country's defense, finances, and foreign relations. Even Bao Dai realized the fiction of Vietnamese independence, remarking that 'What [the French] call a Bao Dai solution turns out to be just a French solution' [Karnow 1997: 187-90, quoted at p. 190].

Later interveners also decided to put a local face on their rule, bringing in exiled leaders they were familiar with, enabling the intervener to get to know them while also, paradoxically, reducing the prospects of generating the significant local support. The Americans took an indirect route to having their preferred leader installed into power in Vietnam and Afghanistan, allowing for the formal decision to be made by those in the country. In Vietnam, Ngo Dinh Diem was named prime minister during the negotiations at Geneva that would end French rule in Indochina. He was formally chosen by Bao Dai, still nominally ruler of the French-created State of Vietnam. The Americans knew Diem because he had spent several years in the United States, living in seminaries, reaching out to leaders in and out of government and across America's political spectrum, and actively campaigning for the leadership post in Vietnam, something he realized could only happen if he gained American support. They liked Diem because he was both anti-communist and anti-French, and the they came to believe that there was 'no one to take [Diem's] place who would serve U.S. interests better' in the words of Donald Heath, ambassador to Vietnam [quoted in Herring 2002: 62]. Bao Dai was uneasy about Diem, but he realized that he was 'well-known to the Americans, who appreciated his intransigence. In their eyes, he was the man best suited for the job, and Washington would not be sparing in its support for him' [Jacobs, 2006: 15-35; Bao Dai quoted at Logevall 2012: 590].

The Soviets and Americans both relied on indirect rule through trusted local leaders following their invasions of Afghanistan. The Soviets decided on Babrak Karmal. Long friendly with the Soviet Union, Karmal had been on the KGB payroll since the 1950s and was a leading figure in the pro-Soviet government that came to power in April 1978. Soon, however, he lost out in factional fighting and was exiled to the Afghan embassy in Prague. As the Soviets were considering invading, they moved Karmal to Moscow, where the KGB worked with him to develop a new Afghan government and a new party platform [Tomsen 2011: 93, 128, 163-64]. The Americans 
engineered Hamid Karzai's selection to lead the Afghan interim government created after their invasion. Karzai had spent much of the late 1990s in Pakistan as part of the anti-Taliban resistance, and he had long urged the Americans to provide assistance, but the Americans only did so after 9/11. By that time Karzai was in Afghanistan, and American policy had changed fundamentally. An American intelligence official summarized these changes: 'Karzai had in his head that he could rally the Pashtuns. Nobody really believed him before $9 / 11$....Even after $9 / 11$ he was not seen as the real guy, until he went inside without any support from us....After the CIA met up with him and reported back, George Tenet made a very quick decision that this is the guy we back - this is the guy who will lead a free Afghanistan' [quoted in Rashid 2009: 86]. The U.S. saw that that happened at the December 2001 Bonn conference. Many Afghans in attendance did not know Karzai and felt they were being pressured by the U.S. to choose him [Rashid 2009: 19-23]. The new leader was, according to the official U.S. military history of the Afghan war, "both pro-Western and anti-Taliban, a rare combination' [Steele 2011: 258].

The case of America in Iraq is somewhat different. It begins in much the same way, with the United States selecting prominent Iraqi exiles to play a leading role in post-invasion Iraq. A particularly influential one was Ahmad Chalabi. He had been the leader of the Iraqi National Conference, an umbrella organization that included a variety of political opinions. While the INC had received support from the CIA in the early 1990s, its failures in Iraq had led the Clinton administration to distance itself from the group. Chalabi did establish good relations with neoconservative figures who were to play an important role in the second Bush administration [Packer 2006: 76-78]. They hoped to hand over power to Chalabi, other exiles, and selected internal Iraqis after the invasion. The Defense Department helped Chalabi get a head start in the transition process, flying him and several hundred followers from Kurdistan to an airport near Baghdad so that they could begin to consolidate their control - at the expense of other political groups [Packer 2006: 140-41].

Yet the exiles soon lost American support. They had predicted that several thousand exiles would be able to control Iraq because the Iraqi administrative apparatus would continue working after Saddam was overthrown. When that prediction did not pan out and there was extensive looting, the exiles were discredited. Soon the Americans would move in a different direction and assume direct control of the country, inserting one of their own, Paul Bremer, to govern [Packer 2006: 140-41]. Bremer arrived in May 2003 and anticipated staying for as long as five years. As head of the Coalition Provisional Authority, Bremer hoped to direct the construction of a new Iraq. While there was an advisory body, the Iraqi National Council, Bremer viewed it with contempt, once arguing that it 'couldn't organize a parade, let alone run the country' [quoted in Jervis 2009: 133]. Yet like the previous British occupiers in Iraq, the policy of direct rule was soon abandoned. It officially ended in June 2004, but the transition process to an Iraqi-led government had begun in late 2003. Still, the United States retained great influence on the selection of the new Iraq leader, if only 
because it had more than 100,000 troops remaining in the country. Now, however, it could merely influence the decision on the new leader by exerting a veto rather than determine the country's new leader. The U.S. still wanted someone it could trust and who was reliable. To illustrate, Bush had an unusual requirement. The President told Bremer that, 'It's important to have someone who's willing to stand up and thank the American people for their sacrifice. I don't expect us to pick a yes man. But at least I want someone who will be grateful.' Ayad Allawi was willing. While he was something of a lowest common denominator among Iraqis, he was a good choice for the United States. Not only was he willing to thank the American president, but he had been on the CIA's payroll for years and 'could be trusted (to a degree that few other Iraqi leaders could) not to go against America's most vital interests' [Jervis 2009: 133].

\section{BUYER'S REMORSE}

Yet having effectively chosen these leaders, relations between the intervener and the client typically deteriorated, to the point where the intervener often sought the removal of the leader it had installed. That distance that will develop between the intervener and the client is probably inevitable for both political and psychological reasons. The client will claim that he knows the country and its people better than the intervener. In addition, no one wants to be seen as a puppet, and clients want to develop some independence. For the intervener, while it wants a client that does its bidding, it also recognizes that strengthening the client's government is a prerequisite for its ultimate withdrawal, and that this requires that the client would develop some independence. Jonathon Steele has summarized these psychological and political pressures on Afghan leaders Karzai and Karmal: 'Karmal and Karzai had been handpicked by a superpower to preserve its strategic interests. They depended on that state economically, politically and above all militarily. Without the imperial forces based in Afghanistan, Karmal and Karzai knew that they could not survive. Hence their flashes of rage at the humiliation and impotence inherent in their situation - and their desperate need to exert independence in small things, if not in anything that seriously mattered' [Steele 2011: 312-13]. Similarly, Diem, a true nationalist, was 'obsessed with the specter of collaboration.... But what option did he have? U.S. material and political support was, and would continue to be for some time to come, crucial to his political survival' [Logevall 2012: 657]. Or, as Charles Tripp has written about Iraq's Faisal, he was 'sovereign of a state that was itself not sovereign' [Tripp 2007: 48].

For the interveners, however, the rage and modest assertions of independence led over time to frustration and anger and, typically, efforts to remove the client. Even Bao Dai, the apolitical playboy emperor chosen by the French, could prove troublesome. He convened a 'National Congress' in October 1953 that called for complete independence from France. The French reacted with fury: President Vincent Auriol 
declared that Bao Dai and the delegates should 'stew in their own juice....We'll withdraw the expeditionary force' [quoted in Logevall 2012: 371-72].

In South Vietnam, while the Americans had been the crucial 'vote' in Diem's selection as prime minister, some became disillusioned with him almost from the start. J. Lawton Collins, President Eisenhower's Special Representative from late 1954 to mid-1955, was especially critical of Diem's government and leadership style, describing him as a 'small, shy diffident man with almost no personal magnetism. I am by no means certain that he has the [inherent] capacity to manage the country during this critical period' [quoted in Logevall 2012: 640]. Collins soon came to advocate Diem's removal from power, but the Eisenhower administration was unwilling to do so [Jacobs 2006: 59-82]. Diem continued to behave in ways disapproved of by the U.S. and mutual tensions increased. The U.S. began to increase its demands on the South Vietnamese leader in the face of increased violence in the early 1960s, e.g., calling on him to remove his brother $\mathrm{Nhu}$, the widely hated chief of the secret police. Diem refused to do so and dropped hints that he would reach out to communist North Vietnam if the pressure continued. By the summer of 1963 the Kennedy administration had had enough and began to communicate with South Vietnamese generals - who had their own reasons for wanting Diem removed - and endorsed their efforts to remove him from power, telling them that it 'would not attempt to thwart a coup' and promising to continue military assistance if one happened. With such assurances, the South Vietnamese generals acted and Diem was removed from power and killed in early November 1963 [Jacobs 2006: 157-83, quoted at p. 167].

The Soviets had installed Babrak Karmal at the time of their arrival in Afghanistan but were soon unhappy with him. He exacerbated rather than healed the split between Khalq and Parcham factions in the ruling party; he had failed to broaden the regime's social base or reach out to large elements of the Afghan populace; and he had not done a good job promoting the revolution's achievements. The Soviets finally decided in early 1986 that he had to be removed for 'health reasons' [Kalinovsky 2011: 95-98; Tomsen 2011: 209-13]. To increase the pressure, a leading KGB official reminded Karmal of what had happened to Hafizullah Amin, his predecessor, who had been killed in the presidential palace: 'Now, comrade Karmal, you should be very careful. Your enemies may kill you.' Karmal understood completely, responding that, 'No. Only my friends can kill me now' [quoted in Steele 2011, p. 117]. Karmal was replaced by Mohammed Najib (Najibullah). Like Karmal, Najibullah was someone the Soviets thought they could work with. He was an ethnic Pashtun, a loyal communist who had been groomed by the KGB since at least 1979, and he had done a good job running the Afghan secret police after 1981. However, the Soviets soon discovered that he, too, was too independent for their tastes. Like Karmal, he promised the Soviets that he would broaden the government and share power, but in practice Najibullah distrusted non-Pashtuns and kept the power ministries in his own hands. While the Soviets were pressing for reforms so that they could leave Afghanistan, Najibullah was pressuring them to stay [Kalinovsky 2011: 95-117; Braithwaite 2011: 275-77]. 
Perhaps the only reason he survived is that the Soviets left before their frustration become so great that they sought his removal.

The Americans also had problems with 'their' Afghan leader, Hamid Karzai. Karzai was disappointed that Western aid was not as extensive as promised, and he publicly urged the U.S. not to reduce its assistance to Afghanistan even as it prepared to invade Iraq. Robert Finn, the first U.S. ambassador to Karzai's government, later argued that the 'Karzai that gives Washington such a headache today is, in large part, a product of how we dealt with him. We didn't give him the resources he needed - be it money or troops' [quoted in Chandrasekaran 2012: 87]. Despite these grievances, Karzai remained loyal to George W. Bush, but the relationship has worsened with the Obama administration where 'Not a single senior U.S. official on the Obama team had a trusting relationship with Karzai' [Rashid 2009: 90]. Special Representative Richard Holbrooke described him as 'incompetent,' while U.S. ambassador Karl Eikenberry identified additional complaints in a secret 2009 cable to Secretary of State Hillary Clinton: 'President Karzai is not an adequate strategic partner...[He] continues to shun any responsibility for any sovereign burden, whether defense, governance, or development...' [Chandrasekaran 2012: 90,124]. Karzai is also frustrated with the United States and has lashed out periodically, saying on one occasion that 'If [the Americans] and the international community pressure me more, I swear I am going to join the Taliban' and on another that 'Afghanistan is not a puppet state' [quoted in Chandrasekaran 2012: 165; Thomsen 2011: 674]. That attitude suggests that Americans have relatively little influence on the Afghan president, while also giving them a reason to disregard his input. When he expressed his disapproval of Obama's counterinsurgency program, for instance, the Americans 'ignored' him because they 'were not willing to give up on COIN, even if the leader of the sovereign nation in which they were fighting had clearly done so' [Chandrasekaran 2012: 166].

What, then, to do about Karzai? Obama was certainly not going to take the route Kennedy took towards Diem, pressing for a coup to remove a difficult client. Rather, some in the administration, particularly Holbrooke, put hope in the Afghan people to vote Karzai from office in the August 2009 presidential election. To facilitate that outcome, Holbrooke hoped to increase the number of candidates in the first round to force a run-off election in which opposition candidates would unite to defeat Karzai. Holbrooke, himself, met publicly with Afghan opposition candidates and ordered the U.S. ambassador to do the same, actions that undoubtedly offended the Afghan President. The day after the election Holbrooke declared, on the basis of only a small percentage of the vote, that one of the opposition candidates might have won and that at a minimum, there would have to be a run-off. Karzai was furious, and insisted that he never wanted to see Holbrooke again. In the end, the election results were so confused and contested that the second place finisher in the initial vote abandoned his campaign for the run-off and Karzai was re-elected to a second term [Chandrasekaran 2012: 91-94]. Not surprisingly, the active but failed American efforts to remove Karzai exacerbated tensions between the two sides. 
The Iraqi cases are somewhat different because, while the British and Americans thought about removing their client, they did not do so. The British were tempted to act against King Faisal in the face of his opposition to the proposed Anglo-Iraq Treaty of 1922. Fortunately for the King, perhaps, and the British, he developed a case of appendicitis allowing the British to temporarily assume direct rule. When the king returned to his position, he expressed support for the treaty [Tripp 2007: 52]. As for the Americans, they did not work to undermine Ayad Allawi, the one who had been selected to lead the Iraqi government after the end of the Coalition Provisional Authority. However, they did express disapproval about his elected successors. For example, the U.S. came to disapprove of Ibrahim Jaafari, who had been selected as prime minister after the January 2005 parliamentary elections, because of his indecisiveness, sectarianism, and tolerance of human rights abuses. It worked actively after the December 2005 elections to prevent Jaafari from returning as prime minister. Eventually, with American prodding, the Iraqis agreed on Nuri Kamal al-Maliki, yet the Americans also became frustrated with him, with some considering supporting his Iraqi opponents. Bush disagreed with that view, however, vowing publicly in late 2007 to support Maliki, in part because there were no better options [Gordon and Trainor 2012: 195-98, 455-59].

\section{CONCLUSIONS}

This article began by documenting the interveners' failures in Vietnam, Iraq, and Afghanistan. Those failures were due, in part, to the attitudes they brought to the effort and to the policies they first adopted. Putting their interests ahead of those of the target country, while not surprising, complicated interveners' efforts because they had few local allies and those they did have were often viewed as puppets. Ignoring the target country's history and the prevailing political/military situation enabled them to exaggerate both the ease with which they could gain control and the goals they could achieve. The inability to reach those goals, or to reach them only after great exertion, probably contributed to the unease at home that was the primary cause of their eventual defeat. Finally, the inability to decide upon a local client and, in some cases, on a system of government forced the intervener to devote much attention on the domestic politics of the target state and not as much on the attainment of its goals.

\section{REFERENCES}

Anderson, T. H. 2011. Bush's Wars, Oxford University Press, New York.

Braithwaite, R. 2011. Afgantsy: The Russians in Afghanistan, 1979-1989, Oxford University Press, New York.

Brigham, R. K. 2008. Iraq, Vietnam, and the Limits of American Power, Public Affairs, New York. Chandrasekaran, R. 2012. Little America: The War Within the War for Afghanistan, Bloomsbury, London. 
Cohen, Steven, ed. 1983. Vietnam: Anthology and Guide to a Television History, Random House, New York.

Evans, R. 2013. The War Before the War: Soviet Precedent in Afghanistan, www.foreignpolicy.com. April 3, 2013.

Gordon, M. R. and Trainor, B. E. 2012. The Endgame: The Inside Story of the Struggle for Iraq, From George W. Bush to Barack Obama, Pantheon, New York.

Herring, G. C. 2002. America's Longest War: The United States and Vietnam, 1950-1975, McGraw Hill, New York.

Institute of Economics and Peace, 2012 Global Terrorism index: Capturing the Impact of Terrorism in the Last Decade (December 2012), http://pl.scribd.com/doc/115891460/Global-TerrorismIndex-Report-2012.

Jacobs, S. 2006. Cold War Mandarin: Ngo Dinh Diem and the Origins of America's War in Vietnam, 1950-1963, Rowman and Littlefield, Lanham, Maryland.

Jervis, D. 2012. Assessments of the American Adventure in Afghanistan, "South African Journal of International Affairs" 19.

Jervis, D. 2009. Mugged by Reality: The American Experience in Iraq, "South African Journal of International Affairs".

Johnson, T. H. and Mason, M. C. 2009. Refighting the Last War: Afghanistan and the Vietnam Template, "Military Review" (November-December 2009).

Jones, S. G. 2009. In the Graveyard of Empires: America's War in Afghanistan, Norton, New York.

Kalinovsky, A. M. 2011. A Long Goodbye: The Soviet Withdrawal from Afghanistan, Harvard, Cambridge.

Karnow, S. 1997. Vietnam: A History, Penguin, New York.

Logevall, F. 2012. Embers of War: The Fall of an Empire and the Making of America's Vietnam, Random House, New York.

Morgan, T. 2010. Valley of Death: The Tragedy of Dien Bien Phu That Led America into the Vietnam War, Random House, New York.

Packer, G. 2006. The Assassin's Gate: America in Iraq, Farrar, Straus, and Giroux, New York.

Rashid, A. 2009. Descent Into Chao, Penguin, New York.

Record, J. and Terrill, W. 2004. Iraq and Vietnam: Similarities and Differences. Strategic Studies Institute, Carlisle, Pennsylvania.

Sluglett, P. 2007. Britain in Iraq: Contriving King and Country, Columbia, New York.

Steele, J. 2011. Ghosts of Afghanistan: Hard Truths and Foreign Myths, Counterpoint, Berkeley, California.

Tierney, D. 2010. How We Fight: Crusades, Quagmires, and the American Way of War, University of Nebraska Press, Lincoln, Nebraska.

Tomsen, P. 2011. The Wars of Afghanistan: Messianic Terrorism, Tribal Conflicts, and the Failures of Great Power, Public Affairs, New York.

Tripp, Charles. 2007. A History of Iraq, Cambridge, New York.

\section{BIOGRAPHY}

David Jervis is a Professor of International Relations at the Maria Curie-Skłodowska University. He has taught for more than 25 years at institutions in America, Germany, and Croatia as well as Poland. His research interests include political change in the non-Western world and American responses to such change. 